\title{
Analysis of DUX4 Expression in Bone Marrow and Re-Discussion of DUX4 Function in the Health and Disease
}

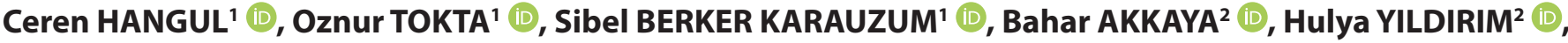 \\ Funda TAYFUN KUPESIZ ${ }^{3}$, Ayse Nur AKINEL ${ }^{3}$
}

Department of 'Medical Biology and Genetics, ${ }^{2}$ Pathology, and ${ }^{3}$ Pediatric Hematology and Oncology, Akdeniz University, Faculty of Medicine, ANTALYA, TURKEY

This work had been was supported by Akdeniz University Research Foundation, Research Number: TYL-2020-5172.

This study had been presented at the 28th annual FSHD Society International Research Congress, June 24-25, 2021.

\section{ABSTRACT}

Objective: DUX4 is an embryonic transcription factor (TF) later silenced in somatic tissues, while active in germline testis cells. Re-expression in somatic cells has been revealed to be present in pathologic conditions such as dystrophy, leukemia, and other cancer types.

Embryonic cells, cancer cells and testis cells that show DUX4 expression are pluri-multipotent cells. This lead us to question "Could DUX4 be a TF that is active in certain types of potent somatic cells?" As a perfect reflection of the potent cell pool, we aimed to reveal DUX4 expression in the bone marrow.

Material and Method: Bone marrow aspiration materials of seven healthy donors aged between 3 and 32 ( 2 males/5 females) were investigated with qPCR analysis after RNA isolation for the presence of DUX4 full length mRNA expression. Samples have been investigated for protein existence of DUX4 via immunohistochemistry in two donors that had sufficient aspiration material.

Results: DUX4 mRNA expression was present in all donors, with higher expression compared to B-actin. DUX4 positive stained cells were also detected by immunohistochemistry.

Conclusion: With these results, novel expression for DUX4 in hematopoietic tissue is described. Further studies on the function of DUX4 in hematopoietic cells can shed light on DUX4-related pathways, and contribute to the treatment of DUX4-related diseases such as B-ALL, other cancers, and facioscapulohumeral muscular dystrophy.

Keywords: DUX4, Bone marrow, Hematopoietic progenitor cells, B-ALL, Cancer, Facioscapulohumeral muscular dystrophy

\section{INTRODUCTION}

DUX4 is a double homeobox transcription factor (TF) that is active in the embryonic period (1-3). It is located on D4Z4 repeat units on chromosome 4q35 (4). In the normal condition, D4Z4 repeat ranges from 11 to 100 units and each of these units consists of 3300 bases (5). At the end of each 3300 bases, DUX4 gene sequence is settled (4). From this sequence, two main isoforms, a long isoform called DUX4-fl (full length) and a short isoform called DUX4s are transcribed with alternative splicing. Expression profiles and roles of these isoforms are divergent. DUX4s can be expressed in some of the somatic cells; however DUX4$\mathrm{fl}$ is expressed only in embryonic cells and germline cells of healthy adults $(6,7)$. Expression of DUX4-fl in somatic tissue is observed in facioscapulohumeral muscular dystrophy (FSHD) and has been revealed to be pathogenic (7). In FSHD, there is a contraction of D4Z4 repeats on chromosome 4 (8). Contraction leads to re-activation of the DUX4 gene in somatic skeletal tissue (9). When this contraction is accompanied by the qA allele in the same chromosome (10), re-activated DUX4 mRNA is stabilised, which is toxic to the skeletal cell (9) leading to apoptosis (11). Other than FSHD, few studies have revealed rare expression of DUX4-fl in somatic cells such as keratinocytes and thymic cells $(12,13)$. Recent searches on cancer have also revealed that DUX4 expression was present in most of the cancer cell types suggesting new roles for DUX4. First studies arrived with the report on CIC-DUX4 fusion in sarcomas (14). Later on, Chew et al. revealed that DUX4-fl is actively expressed in 25 different cancer types (15). B-ALL is one of the other newly discovered DUX4-expressing cancer types (16). In ALL, the most common genetic DUX4 related event is DUX4 fusion with other ALL specific genes such as $E R G$ (17). This fusion mostly causes DUX4 overexpression leading to cell transformation and B-ALL (18). However, detailed DUX4 related pathophysiologic mechanisms in B-ALL are not known yet (16). Interestingly, there is no 
information on whether DUX4 expression is present in healthy hematopoietic tissue. For this reason, in this study we investigated the presence of DUX4-fl expression in bone marrow aspirates of healthy donors. By investigating multipotent healthy hematopoietic sample, we aimed to get an answer for two main questions: i) Like its expression in malignant hematopoietic cells, is DUX4 expression present in healthy hematopoietic cells? and ii) Is DUX4fl expression present in somatic undifferentiated cell types with high proliferation potential?

\section{MATERIAL and METHOD}

This study had been approved by the Akdeniz University Faculty of Medicine Clinical Research Ethical Committee; Decision Number: 1087, Date: 27.11.2019

\section{Donors}

Two males, five females, a total of seven healthy bone marrow donors have been included in this study. Their ages varied between 3 and 32. Age and gender information of the donors have been summarised in Table I.

\section{Bone Marrow Sampling}

After the application of topical anaesthesia, bone marrow material has been obtained with superior iliac crest aspiration.

\section{RNA extraction}

Total RNA isolation from bone marrow samples has been performed with the Qiamp RNA blood mini kit (Qiagen).

\section{cDNA synthesis}

Obtained total RNA was converted into cDNA using a Blue-Ray PCR device in accordance with the protocol with Applied Biosystems High-Capacity cDNA Reverse Transcription Kit (4368814). The converted cDNA samples were stored at $-20^{\circ} \mathrm{C}$. Reverse transcriptase PCR conditions were: $25^{\circ} \mathrm{C} 10$ minutes, $37^{\circ} \mathrm{C} 120$ minutes, $85^{\circ} \mathrm{C} 5$ minutes, $4^{\circ} \mathrm{C} \infty$.

Table I: Gender and age of healthy donors.

\begin{tabular}{lcc}
\hline Donors & Age & Gender \\
\hline Donor 1 & 3 & female \\
\hline Donor 2 & 4 & female \\
\hline Donor 3 & 9 & female \\
\hline Donor 4 & 10 & male \\
\hline Donor 5 & 16 & female \\
\hline Donor 6 & 23 & male \\
\hline Donor 7 & 32 & female \\
\hline
\end{tabular}

\section{Spectrophotometric Measurement of cDNA Samples}

Amount and purity measurements of the isolated cDNA samples were determined with a spectrophotometer (Quawell / Q9000B). For the measurement, $2 \mu \mathrm{l}$ of cDNA sample was loaded into the spectrophotometer device. The purity and amount of cDNA were determined in $\mathrm{ng} / \mu \mathrm{l}$ with the ratio of measurements obtained at $260 \mathrm{~nm}$ and $280 \mathrm{~nm}$ wavelengths of the samples. cDNA samples were diluted to $100 \mathrm{ng} / \mu \mathrm{l}$ for use in PCR studies.

\section{Quantitative Real-Time Polymerase Chain Reaction (qRT-PCR)}

Applied Biosystems ${ }^{\mathrm{TM}}$ StepOnePlus ${ }^{\mathrm{TM}}$ Real-Time PCR device and PowerUp ${ }^{\mathrm{TM}}$ SYBRTM Green Master Mix (A25776) kit were used in accordance with the protocol to determine the level of DUX4 gene expression. Mixes containing the cDNAs of each donor were added to the 96-well plate in at least three replicates. For the analysed DUX4 gene, a negative control plate containing no cDNA was loaded. The $B$-actin gene, which is the housekeeping gene, was used as control gene in the analyses. The primer pair for B-actin is 5'-CCTGGCACCCAGCACAAT3'(forward) and 5'-GCCGATCCACACGGAGTACT-3' (reverse). The primer sequences used for the DUX4-fl are CAAGGGGTGCTTGCGCCACCCACGT (forward) and GGGGTGCGCACTGCGCGCAGGT (reverse). qPCR conditions were: $95^{\circ} \mathrm{C} 10$ minutes, $95^{\circ} \mathrm{C} 15$ seconds, $60^{\circ} \mathrm{C}$ 1 minute, 40 cycles.

qPCR analysis had been performed at least three times for each sample. The average of the results was calculated and integrated into the graphic by converting into the nearest integer.

\section{Agarose Gel Electrophoresis}

To control the presence of DUX4 cDNA conversion and amplicon size of DUX4- $f$ transcript, RT-PCR products were run on $2 \%$ agarose gel.

\section{Immunohistochemistry}

Bone marrow aspiration materials from two donors were immunohistochemically stained for DUX4 using rabbit monoclonal IgG E5-5 antibody (cloneP4H2) raised against a synthetic peptide corresponding to the $\mathrm{C}$-terminus of the human DUX4 protein (catalog no ab124699; Abcam). E5-5 antibody recognizes the C terminal domain of DUX4 (19). An automated DAKO Omnis staining platform was used to perform all immunohistochemical procedures, with the aid of the Optiview detection kit. Antibody staining was performed at 1:50 dilution. 


\section{RESULTS}

\section{All of Seven Donors had DUX4 mRNA Expression}

mRNA expression of DUX4 was revealed to be present in each of the bone marrow samples. DUX4 expression level exhibited similar levels in between the bone marrow samples of donors and no significant difference was noted depending on age and gender (Figure 1A). In addition, the expression level of DUX4 was higher in each sample compared to the level of $B$-actin expression (Figure 1B).

\section{DUX4 Protein Staining was Positive in the Cells that were Relatively Larger}

Donor 2 and donor 3 , who had sufficient aspiration material, were also investigated with DUX4 protein staining. Both donor 2 and 3 had a portion of positively staining cells in their bone marrow aspirates. Staining density was low. Positively stained hematopoietic cells were observed to be larger in size relative to negatively stained cells in bone marrow aspirates (Figure 2A,B and 3A).

Positive staining of two huge cells revealed a positive expression of DUX4 protein in megakaryocytes (Figure $3 B)$.

\section{DISCUSSION}

DUX4- $\mathrm{fl}$ is an active TF expressed in embryonic pluripotent cells $(2,3,20)$. Normal function of DUX4-fl is attributed to early developmental stages. However recent proofs of DUX4-fl expression in late-differentiating keratinocytes (12), cells in the thymus (13), and lymphoblastoid cells (21, 22) have revealed that DUX4-fl expression is present in somatic and in differentiating cells. Human mesenchymal stromal cells (hMSC) (23) and mesangioblasts of facioscapulohumeral muscular dystrophy (FSHD) (24) are the other somatic/potent cells revealed to express DUX4. As another supporting data, some types of cancer cells,
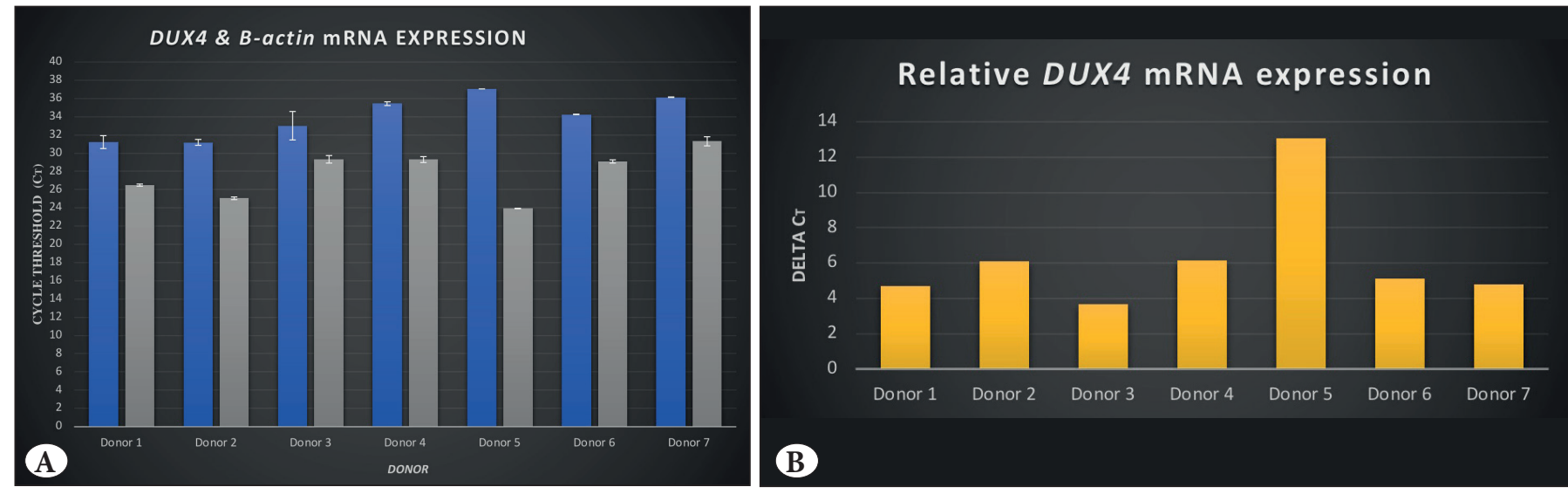

Figure 1: A) qPCR analysis of seven healthy donors with different ages and gender. Blue bars represent DUX4 mRNA expression and grey bars represent housekeeping $B$-actin mRNA expression. B) DeltaCT values of DUX-fl mRNA expression in bone marrow aspirates.
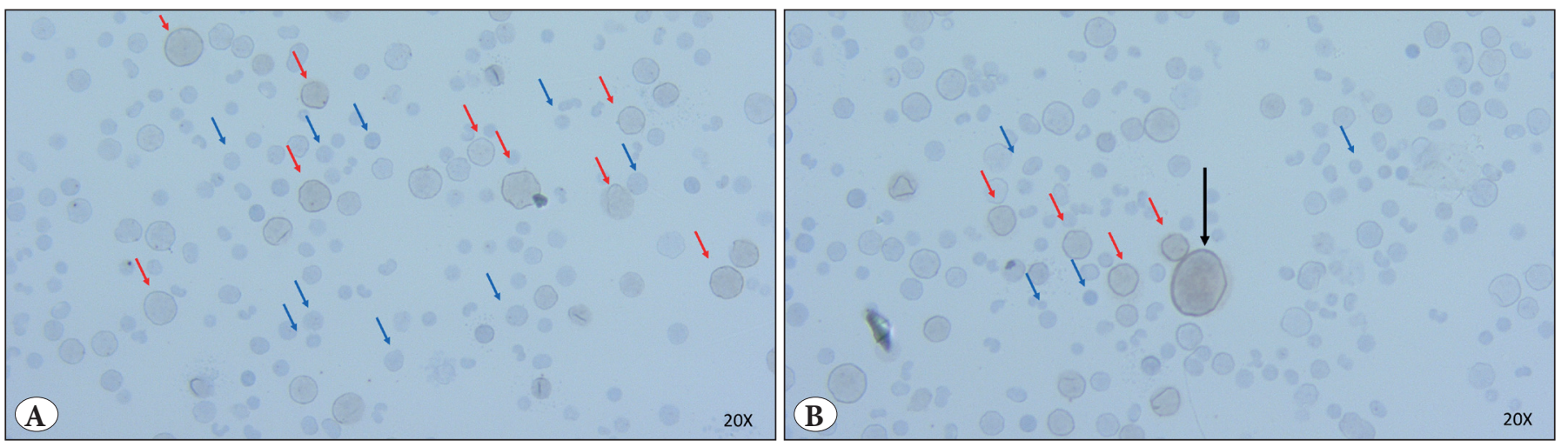

Figure 2: DUX4 Immunohistochemistry figures of bone marrow aspirates of Donor 2. A) Red arrows indicate brown cells that are positive for DUX4 protein, blue arrows indicate DUX4 negative cells. B) Red arrows indicate DUX4 positive cells, blue arrows indicate DUX4 negative cells, black arrow indicates DUX4 positive cell with its huge nucleus. All photographs have been taken $20 \mathrm{X}$ microscopic magnification. 
which are mostly somatic and have a high proliferation rate, were positive for DUX4 and the first study came with CIC/DUX4 fusion (14). In another comprehensive study, Chew et al. revealed DUX4-fl was expressed in 25 different types of cancer cells (15). Interestingly, B-ALL was one of the DUX4 related cancers $(17,25-27)$. It was shown that DUX4 expression lead defective B cell differentiation and transformation $(18,28)$. All aforementioned findings lead us to investigate DUX4-fl expression in healthy multipotent/progenitor hematopoietic cells, which has not been revealed before.

DUX4 is a pioneer transcription factor and has essential roles in zygotic gene activation (1-3). Pioneer transcription factors initiate cell differentiation, and they activate cell specific genes. Pioneer TFs need to be expressed at certain time points and in precise amounts: they have spatiotemporal speciality. For example, PAX7 is another homeobox TF (29) that has exchangeable domains with DUX4 (30). Mayran et al. have revealed that even transient PAX7 expression is sufficient for the cell fate (29). Similar to that, the quantity of expression level (31) and spatiotemporal specificity (32) are critical for DUX4 expression. Expression of transient bursts of stochastic expression in a small proportion of FSHD myonuclei (6) especially supports the spatiotemporal pattern of DUX4.

DUX4 binds to its target genes via its $\mathrm{N}$ terminal domain (4) and activates transcription via its $C$ terminal domain by attracting histone acetyl transferase (HAT) complexes to that area (33). DUX4s does not contain a $\mathrm{C}$ terminal while DUX4-fl contains a $\mathrm{C}$ terminal domain and can activate gene expression. In addition, DUX4s is normally expressed in somatic tissues, while DUX4- $\mathrm{fl}$ is assumed not to be expressed in healthy somatic tissues (6). Because of these, we preferred to investigate DUX-fl in somatic hematopoietic cells, and used DUX4- $f l$ specific primers for mRNA analysis and antibody that recognises C-terminal domain for the protein analysis. Two males and five females aged between 3 to 32 were analysed for DUX4 expression. As a result, in mRNA level, we detected that DUX4- $f$ l were present and expression levels were close to each other in all of the samples without any exception. Remarkably, expression of DUX4-fl mRNA levels was higher compared to $B$-actin levels (Figure 1A,B). No significant difference was present in the expression of DUX4 depending on age and gender factors; except a relative higher level in Donor 5 who was an adolescent female. This may be related to effect of estradiol on DUX4 that had been revealed in FSHD studies in skeletal tissue (34-36). It can be interesting to investigate this in detail in future studies. Regardless of non-significant level differences, it might be said that our data revealed present DUX4-fl expression in seven healthy somatic bone marrow cells without exception, independent of age and gender factors. This novel data can indicate that DUX4- $f$ l has evident function(s) in somatic healthy hematopoietic cells.

In order to observe whether DUX4 expression is present at the protein level in the hematopoietic cells, we performed immunohistochemical staining of the semi-liquid aspirates of two donors that had remaining aspiration materials. In these preparations, slight staining has been observed (Figure 2 and 3), indicating a low expression level of DUX4-fl similar to that observed in FSHD cells $(6,9,37)$. Slight staining is compatible with its pioneer role in other cell types. This slight positive staining was detected in not all but some part of the cells (Figure 2A,B, 3A) and was remarkably larger in size compared to negatively stained ones (Figure 2A and 3A). In hematopoietic tissue, larger cells indicate progenitor cells that are in the earlier stages of differentiation (38). Because of that, positive staining

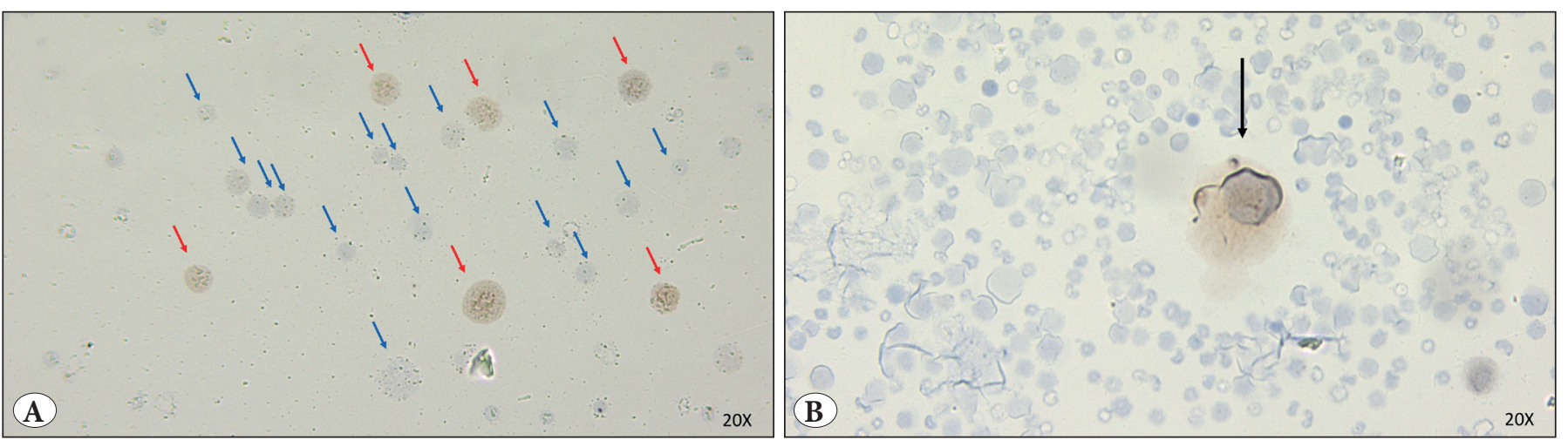

Figure 3: DUX4 Immunohistochemistry figures of bone marrow aspirates of Donor 3. A) Red arrows indicate brown cells that are positive for DUX4 protein, blue arrows indicate DUX4 negative cells. B) Black arrow indicates DUX4 positive huge cell with an empty cytoplasmic area around, indicating a megakaryocyte. All photographs have been taken 20X microscopic magnification. 
in the cells with larger nuclei might suggest that DUX4 is an active TF especially in progenitor hematopoietic cells that came into play in earlier stages and that might be in the less differentiated status. Partial positive staining of the cell population might also support the spatiotemporal expression of DUX4. Interestingly, the observed megakaryocytic cells that had staining with a huge nucleus (Figure 3B) may indicate an additional role of DUX4 for thrombocyte function. DUX4 expression in megakaryocytic cells has not been revealed before and might be valuable for understanding thrombocyte-related diseases. Because of this, it is worthwhile and necessary to identify cell type specific expression of DUX4 in future studies.

Since its direct genetic relationship and numerous related studies in literature, FSHD provides most of the information on the function of DUX4. In a developmental model on FSHD it was suggested that DUX4-fl is normally expressed in early development and suppressed during cellular differentiation (6). However, recent results indicate that DUX4-fl is also expressed in later phases of cellular differentiation. Gannon et al. have revealed that latedifferentiating keratinocytes expressed DUX4 (12). Jones and Banerji et al. have revealed DUX-fl expression in lymphoblastoid cells $(21,22)$ and Das and Chadwick have revealed DUX4 expression in the cells of thymus (13). It was revealed that some of the healthy muscle- derived cells also exhibited DUX4 expression (31). These cells might be in the later phases of differentiation. Supporting that, we observed easier detection of DUX4 protein in first passages (observationaldata) in ourpreviousstudy on in vitro estradiol treatment in FSHD cell culture (36). On the other hand, with the presence of DUX4-fl in pluripotent hematopoietic cells, this present study revealed that expression of DUX4fl not only specific to late differentiating somatic cells, but it can also be expressed in the earlier phases of cellular differentiation. Supporting this, DUX4 expression in early differentiation was revealed to be present also in hMSCs (23). Expression in the earlier phases of differentiation might shed light on other DUX4 related diseases such as FSHD. Deficiency or spatiotemporal disturbance of DUX4 at earlier stages of cell differentiation might explain FSHD. Supporting that DUX4-fl expression in differentiated skeletal cells is not sufficient for FSHD to occur (31). Our results might signify a hypothesis: deficiency or disturbance in the critical spatiotemporal timing and amount-quantity of DUX4 expression could result in pathology in the precursor potent cells at earlier stages and end up with a decreased healthy cell pool. Observation of molecular disease markers in fetal FSHD muscles is compatible with early disturbance of DUX4 (39). Stabilization or de- repression of re-expressed DUX4 via accomplishing qA allele, SMCHD1 or DNMT3B or LRIF1 mutations (40-42) can contribute to spatiotemporal disturbance of DUX4 and lead to the DUX4 toxicity observed in later phases of differentiation. There are multiple treatment trials that aim to inhibit DUX4. Inhibition of DUX4 can prevent these cells from going into apoptosis by eliminating DUX4 toxicity in differentiated FSHD cells. However, it might not provide sufficient clinical improvement in case of a deficiency or disturbance of DUX4 in the early stages. Additionally and importantly, DUX4 inhibition might cause side effects related to the aforementioned cell types that actively need DUX4 expression.

In summary, with the present study it was shown that DUX4 is an active TF in progenitor hematopoietic cells. We suggest that DUX4 expression in earlier stages of cell differentiation can be critical, and DUX4 deficiency and/or spatiotemporal DUX4 disturbance might be related to the pathology of diseases (Figure 4A,B).

In conclusion, DUX4-fl, which is assumed to have rare expression in somatic cells, was found to be present in healthy bone marrow aspirates at both the mRNA and protein level in this study. With this data, it was revealed that the DUX4 expression shown in hematologic malignancy, which is said to be re-expressed in B-ALL, is already expressed by some part of healthy bone marrow cells. The obtained data from this study indicate that the expression of DUX4 should be reviewed and studied in all tissues in future studies, especially in progenitor potent cells. Clarifying the role of DUX4 in potent healthy somatic cells might provide key information for the pathophysiology of B-ALL, other DUX4 related cancers, and FSHD. With further information, more comprehensive treatment strategies can be developed in DUX4 related diseases.

\section{Study Limitations}

Since it is an invasive approach, bone marrow sampling in a separate study is not ethical. Therefore, this study had been carried out using bone marrow samples from healthy bone marrow donors, remaining after transplantation. Because of this, a limited amount and number of materials could be examined.

\section{Conflict of Interest}

All authors declare that they have no conflict of interest.

\section{Authorship Contributions}

Concept: CH, SBK, Design: CH, SBK, OT, BA, HY, FTK, ANA, Data collection or processing: OT, CH, BA, HY, FTK, ANA, SBK, Analysis or Interpretation: CH, OT, SBK, Literature search: CH, SBK, OT, BA, HY, FTK, ANA, Writing: CH, SBK, OT, BA, HY, FTK, ANA, Approval: CH, SBK, OT, BA, HY, FTK, ANA. 


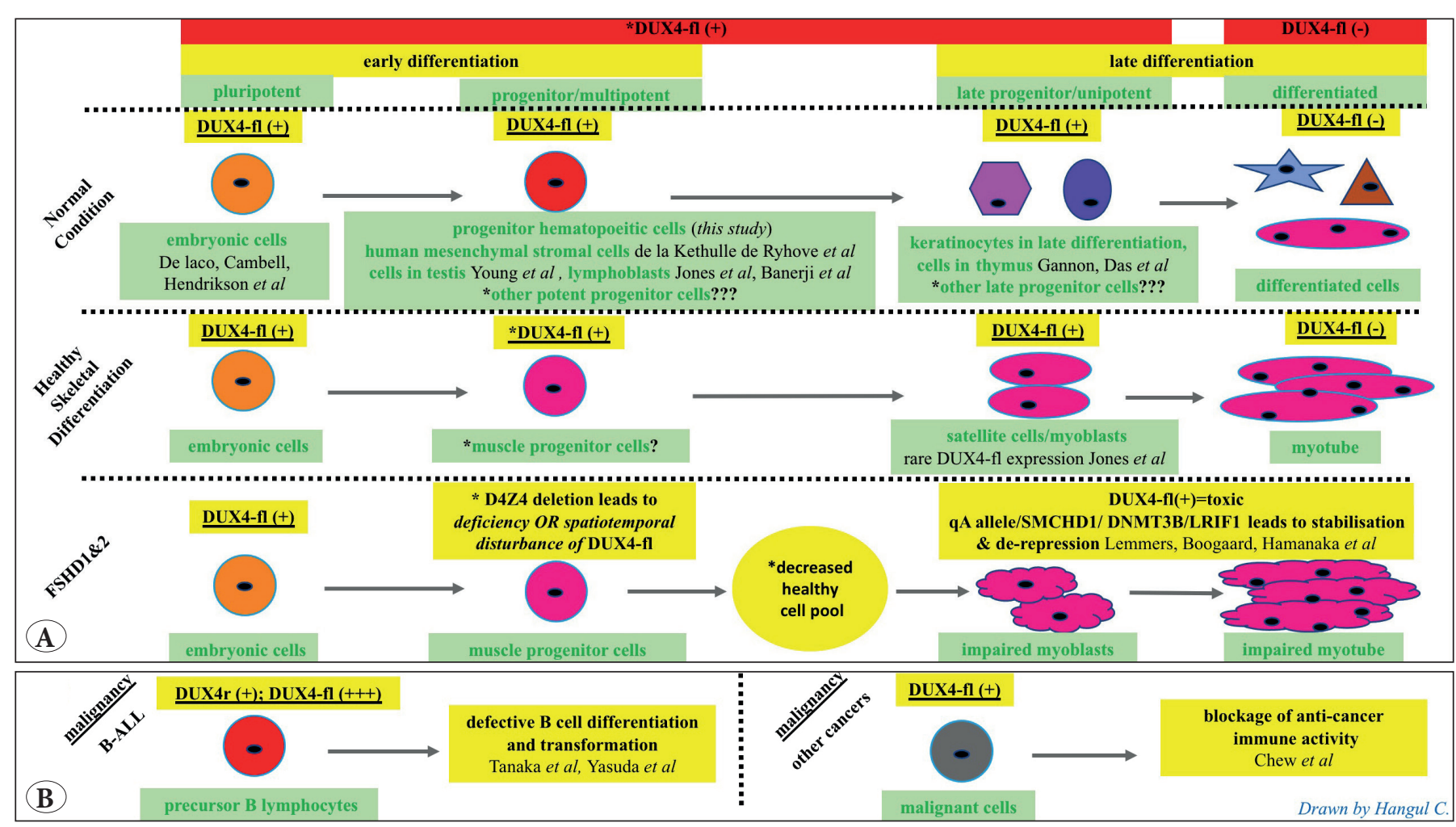

Figure 4: Schematic presentation for the DUX4 role in (A) healthy hematopoietic cells, healthy embryonic cells, healthy skeletal differentiation and FSHD; (B) in malignancy. Revealed knowledge referred with authors.

${ }^{*}$ Asterisks indicate additional hypothesis that is suggested for the role of DUX4. DUX4-fl; full length, DUX4r; DUX4 re-arrangement/fusion.

\section{REFERENCES}

1. Campbell AE, Belleville AE, Resnick R, Shadle SC, Tapscott SJ. Facioscapulohumeral dystrophy: Activating an early embryonic transcriptional program in human skeletal muscle. Hum Mol Genet. 2018;27(R2):R153-R62.

2. De Iaco A, Planet E, Coluccio A, Verp S, Duc J, Trono D. DUXfamily transcription factors regulate zygotic genome activation in placental mammals. Nat Genet. 2017;49:941-5.

3. Hendrickson PG, Dorais JA, Grow EJ, Whiddon JL, Lim JW, Wike CL, Weaver BD, Pflueger C, Emery BR, Wilcox AL, Nix DA, Peterson CM, Tapscott SJ, Carrell DT, Cairns BR. Conserved roles of mouse DUX and human DUX4 in activating cleavagestage genes and MERVL/HERVL retrotransposons. Nat Genet. 2017;49:925-34.

4. Gabriels J, Beckers MC, Ding H, De Vriese A, Plaisance S, van der Maarel SM, Padberg GW, Frants RR, Hewitt JE, Collen D, Belayew A. Nucleotide sequence of the partially deleted D4Z4 locus in a patient with FSHD identifies a putative gene within each 3.3 kb element. Gene. 1999;236:25-32.

5. van Deutekom JC, Wijmenga C, van Tienhoven EA, Gruter AM, Hewitt JE, Padberg GW, van Ommen GJ, Hofker MH, Frants RR. FSHD associated DNA rearrangements are due to deletions of integral copies of a $3.2 \mathrm{~kb}$ tandemly repeated unit. Hum Mol Genet. 1993;2:2037-42.
6. Snider L, Geng LN, Lemmers RJLF, Kyba M, Ware CB, Nelson AM, Tawil R, Filippova GN, van der Maarel SM, Tapscott SJ, Miller DG. Facioscapulohumeral dystrophy: Incomplete suppression of a retrotransposed gene. Plos Genet. 2010;6.

7. Young JM, Whiddon JL, Yao Z, Kasinathan B, Snider L, Geng LN, Balog J, Tawil R, van der Maarel SM, Tapscott SJ. DUX4 binding to retroelements creates promoters that are active in FSHD muscle and testis. Plos Genet. 2013;9:e1003947.

8. Wijmenga C, Hewitt JE, Sandkuijl LA, Clark LN, Wright TJ, Dauwerse HG, Gruter AM, Hofker MH, Moerer P, Williamson R. Chromosome 4q DNA rearrangements associated with facioscapulohumeral muscular dystrophy. Nat Genet. 1992;2:26-30.

9. Lemmers RJ, van der Vliet PJ, Klooster R, Sacconi S, Camano P, Dauwerse JG, Snider L, Straasheijm KR, van Ommen GJ, Padberg GW, Miller DG, Tapscott SJ, Tawil R, Frants RR, van der Maarel SM. A unifying genetic model for facioscapulohumeral muscular dystrophy. Science. 2010;329:1650-3.

10. Lemmers RJ, de Kievit P, Sandkuijl L, Padberg GW, van Ommen GJ, Frants RR, van der Maarel SM. Facioscapulohumeral muscular dystrophy is uniquely associated with one of the two variants of the 4q subtelomere. Nat Genet. 2002;32:235-6.

11. Kowaljow V, Marcowycz A, Ansseau E, Conde CB, Sauvage S, Matteotti C, Arias C, Corona ED, Nunez NG, Leo O, Wattiez R, Figlewicz D, Laoudj-Chenivesse D, Belayew A, Coppee F, Rosa AL. The DUX4 gene at the FSHD1A locus encodes a proapoptotic protein. Neuromuscul Disord. 2007;17:611-23. 
12. Gannon OM, Merida de Long L, Saunders NA. DUX4 is derepressed in late-differentiating keratinocytes in conjunction with loss of H3K9me3 epigenetic repression. J Invest Dermatol. 2016;136:1299-302.

13. Das S, Chadwick BP. Influence of repressive histone and DNA methylation upon D4Z4 transcription in non-myogenic cells. PLoS One. 2016;11:e0160022.

14. Kawamura-Saito M, Yamazaki Y, Kaneko K, Kawaguchi N, Kanda H, Mukai H, Gotoh T, Motoi T, Fukayama M, Aburatani H, Takizawa T, Nakamura T. Fusion between CIC and DUX4 up-regulates PEA3 family genes in Ewing-like sarcomas with t (4; 19) (q35; q13) translocation. Hum Mol Genet. 2006;15:2125-37.

15. Chew GL, Campbell AE, De Neef E, Sutliff NA, Shadle SC, Tapscott SJ, Bradley RK. DUX4 suppresses MHC class I to promote cancer immune evasion and resistance to checkpoint blockade. Dev Cell. 2019;50:658-671-57.

16. Rehn JA, O'Connor MJ, White DL, Yeung DT. DUX huntingclinical features and diagnostic challenges associated with DUX4rearranged leukaemia. Cancers (Basel). 2020;12:2815.

17. Zhang J, McCastlain K, Yoshihara H, Xu B, Chang Y, Churchman ML, Wu G, Li Y, Wei L, Iacobucci I, Liu Y, Qu C, Wen J, Edmonson M, Payne-Turner D, Kaufmann KB, Takayanagi SI, Wienholds E, Waanders E, Ntziachristos P, Bakogianni S, Wang J, Aifantis I, Roberts KG, Ma J, Song G, Easton J, Mulder HL, Chen X, Newman S, Ma X, Rusch M, Gupta P, Boggs K, Vadodaria B, Dalton J, Liu Y, Valentine ML, Ding L, Lu C, Fulton RS, Fulton L, Tabib Y, Ochoa K, Devidas M, Pei D, Cheng C, Yang J, Evans WE, Relling MV, Pui CH, Jeha S, Harvey RC, Chen IL, Willman CL, Marcucci G, Bloomfield CD, Kohlschmidt J, Mrozek K, Paietta E, Tallman MS, Stock W, Foster MC, Racevskis J, Rowe JM, Luger S, Kornblau SM, Shurtleff SA, Raimondi SC, Mardis ER, Wilson RK, Dick JE, Hunger SP, Loh ML, Downing JR, Mullighan CG, St. Jude Children's Research Hospital-Washington University Pediatric Cancer Genome P. Deregulation of DUX4 and ERG in acute lymphoblastic leukemia. Nat Genet. 2016;48:1481-9.

18. Yasuda T, Tsuzuki S, Kawazu M, Hayakawa F, Kojima S, Ueno T, Imoto N, Kohsaka S, Kunita A, Doi K, Sakura T, Yujiri T, Kondo E, Fujimaki K, Ueda Y, Aoyama Y, Ohtake S, Takita J, Sai E, Taniwaki M, Kurokawa M, Morishita S, Fukayama M, Kiyoi H, Miyazaki Y, Naoe T, Mano H. Recurrent DUX4 fusions in B cell acute lymphoblastic leukemia of adolescents and young adults. Nat Genet. 2016;48:569-74.

19. Geng LN, Tyler AE, Tapscott SJ. Immunodetection of human double homeobox 4. Hybridoma (Larchmt). 2011, 30:125-30.

20. Whiddon JL, Langford AT, Wong CJ, Zhong JW, Tapscott SJ. Conservation and innovation in the DUX4-family gene network. Nat Genet. 2017;49:935-40.

21. Jones TI, Himeda CL, Perez DP, Jones PL. Large family cohorts of lymphoblastoid cells provide a new cellular model for investigating facioscapulohumeral muscular dystrophy. Neuromuscul Disord. 2017;27:221-38.

22. Banerji CRS, Panamarova M, Zammit PS. DUX4 expressing immortalized FSHD lymphoblastoid cells express genes elevated in FSHD muscle biopsies, correlating with the early stages of inflammation. Hum Mol Genet. 2020;29:2285-99.
23. de la Kethulle de Ryhove L, Ansseau E, Nachtegael C, Pieters K, Vanderplanck C, Geens M, Sermon K, Wilton SD, Coppee F, Lagneaux L, Belayew A. The role of D4Z4-encoded proteins in the osteogenic differentiation of mesenchymal stromal cells isolated from bone marrow. Stem Cells Dev. 2015;24:2674-86.

24. Dellavalle A, Sampaolesi M, Tonlorenzi R, Tagliafico E, Sacchetti B, Perani L, Innocenzi A, Galvez BG, Messina G, Morosetti R, Li S, Belicchi M, Peretti G, Chamberlain JS, Wright WE, Torrente Y, Ferrari S, Bianco P, Cossu G. Pericytes of human skeletal muscle are myogenic precursors distinct from satellite cells. Nat Cell Biol. 2007;9:255-67.

25. Marincevic-Zuniga Y, Dahlberg J, Nilsson S, Raine A, Nystedt S, Lindqvist CM, Berglund EC, Abrahamsson J, Cavelier L, Forestier E, Heyman M, Lönnerholm G, Nordlund J, Syvänen AC. Transcriptome sequencing in pediatric acute lymphoblastic leukemia identifies fusion genes associated with distinct DNA methylation profiles. J Hematol Oncol. 2017;10:148.

26. Liu YF, Wang BY, Zhang WN, Huang JY, Li BS, Zhang M, Jiang L, Li JF, Wang MJ, Dai YJ, Zhang ZG, Wang Q, Kong J, Chen B, Zhu YM, Weng XQ, Shen ZX, Li JM, Wang J, Yan XJ, Li Y, Liang YM, Liu L, Chen XQ, Zhang WG, Yan JS, Hu JD, Shen SH, Chen J, Gu LJ, Pei DQ, Li YJ, Wu G, Zhou X, Ren RB, Cheng C, Yang JJ, Wang KK, Wang SY, Zhang JH, Mi JQ, Pui CH, Tang JY, Chen $\mathrm{Z}$, Chen SJ. Genomic profiling of adult and pediatric B-cell acute lymphoblastic leukemia. Ebiomedicine. 2016;8:173-83.

27. Li JF, Dai YT, Lilljebjorn H, Shen SH, Cui BW, Bai L, Liu YF, Qian MX, Kubota Y, Kiyoi H, Matsumura I, Miyazaki Y, Olsson L, Tan AM, Ariffin H, Chen J, Takita J, Yasuda T, Mano H, Johansson B, Yang JJ, Yeoh AEJ, Hayakawa F, Chen Z, Pui CH, Fioretos T, Chen SJ, Huang JY. Transcriptional landscape of B cell precursor acute lymphoblastic leukemia based on an international study of 1,223 cases. P Natl Acad Sci USA. 2018;115:E11711-20.

28. Yoshimoto T, Tanaka M, Homme M, Yamazaki Y, Takazawa Y, Antonescu CR, Nakamura T. CIC-DUX4 induces small round cell sarcomas distinct from ewing sarcoma. Cancer Res. 2017;77:2927-37.

29. Mayran A, Khetchoumian K, Hariri F, Pastinen T, Gauthier Y, Balsalobre A, Drouin J. Pioneer factor Pax7 deploys a stable enhancer repertoire for specification of cell fate. Nat Genet. 2018;50:259-69.

30. Bosnakovski D, Toso EA, Hartweck LM, Magli A, Lee HA, Thompson ER, Dandapat A, Perlingeiro RCR, Kyba M. The DUX4 homeodomains mediate inhibition of myogenesis and are functionally exchangeable with the Pax7 homeodomain. J Cell Sci. 2017;130:3685-97.

31. Jones TI, Chen JC, Rahimov F, Homma S, Arashiro P, Beermann ML, King OD, Miller JB, Kunkel LM, Emerson CP Jr., Wagner KR, Jones PL. Facioscapulohumeral muscular dystrophy family studies of DUX4 expression: Evidence for disease modifiers and a quantitative model of pathogenesis. Hum Mol Genet. 2012;21:4419-30.

32. Chau J, Kong X, Viet Nguyen N, Williams K, Ball M, Tawil R, Kiyono T, Mortazavi A, Yokomori K. Relationship of DUX4 and target gene expression in FSHD myocytes. Hum Mutat. 2021, 42:421-33. 
33. Choi SH, Gearhart MD, Cui ZY, Bosnakovski D, Kim M, Schennum N, Kyba M. DUX4 recruits p300/CBP through its C-terminus and induces global H3K27 acetylation changes. Nucleic Acids Res. 2016;44:5161-73.

34. Teveroni E, Pellegrino M, Sacconi S, Calandra P, Cascino I, Farioli-Vecchioli S, Puma A, Garibaldi M, Morosetti R, Tasca G, Ricci E, Trevisan CP, Galluzzi G, Pontecorvi A, Crescenzi M, Deidda G, Moretti F. Estrogens enhance myoblast differentiation in facioscapulohumeral muscular dystrophy by antagonizing DUX4 activity. J Clin Invest. 2017;127:1531-45.

35. Hangul C, Bozkurt S, Bilge U, Ozdem S, Altunbas H, Uysal H, Koc F, Karauzum S. The ratios of estradiol and progesterone to testosterone influence the severity of facioscapulohumeral muscular dystrophy. Neurol Sci Neurophysiol. 2020;37:190.

36. Hangul C, Celik E, Kaya H, Eroglu O, Uysal H, Karauzum S. Estradiol differentially regulates DUX4, $\beta$-catenin and PAX3/ PAX7 in primary myoblasts of facioscapulohumeral muscular dystrophy patients. Turkish Journal of Biochemistry. 2020.

37. Dixit M, Ansseau E, Tassin A, Winokur S, Shi R, Qian H, Sauvage S, Matteotti C, van Acker AM, Leo O, Figlewicz D, Barro M, Laoudj-Chenivesse D, Belayew A, Coppee F, Chen YW. DUX4, a candidate gene of facioscapulohumeral muscular dystrophy, encodes a transcriptional activator of PITX1. Proc Natl Acad Sci U S A. 2007;104:18157-62.

38. Collins PC, Patel SD, Papoutsakis ET, Miller WM. Nucleisize distributions as predictive tools of hematopoietic cell proliferation. Cytotherapy. 1999;1:99-109.
39. Ferreboeuf M, Mariot V, Bessieres B, Vasiljevic A, Attie-Bitach T, Collardeau S, Morere J, Roche S, Magdinier F, Robin-Ducellier J, Rameau P, Whalen S, Desnuelle C, Sacconi S, Mouly V, ButlerBrowne G, Dumonceaux J. DUX4 and DUX4 downstream target genes are expressed in fetal FSHD muscles. Hum Mol Genet. 2014;23:171-81.

40. Lemmers RJ, Tawil R, Petek LM, Balog J, Block GJ, Santen GW, Amell AM, van der Vliet PJ, Almomani R, Straasheijm KR, Krom YD, Klooster R, Sun Y, den Dunnen JT, Helmer Q, Donlin-Smith CM, Padberg GW, van Engelen BG, de Greef JC, Aartsma-Rus AM, Frants RR, de Visser M, Desnuelle C, Sacconi S, Filippova GN, Bakker B, Bamshad MJ, Tapscott SJ, Miller DG, van der Maarel SM. Digenic inheritance of an SMCHD1 mutation and an FSHD-permissive D4Z4 allele causes facioscapulohumeral muscular dystrophy type 2. Nat Genet. 2012;44:1370-4.

41. van den Boogaard ML, Lemmers R, Balog J, Wohlgemuth M, Auranen M, Mitsuhashi S, van der Vliet PJ, Straasheijm KR, van den Akker RFP, Kriek M, Laurense-Bik MEY, Raz V, van Ostaijen-Ten Dam MM, Hansson KBM, van der Kooi EL, KiuruEnari S, Udd B, van Tol MJD, Nishino I, Tawil R, Tapscott SJ, van Engelen BGM, van der Maarel SM. Mutations in DNMT3B modify epigenetic repression of the $\mathrm{D} 4 \mathrm{Z} 4$ repeat and the penetrance of facioscapulohumeral dystrophy. Am J Hum Genet. 2016;98:1020-9.

42. Hamanaka K, Sikrova D, Mitsuhashi S, Masuda H, Sekiguchi Y, Sugiyama A, Shibuya K, Lemmers R, Goossens R, Ogawa M, Nagao K, Obuse C, Noguchi S, Hayashi YK, Kuwabara S, Balog J, Nishino I, van der Maarel SM. Homozygous nonsense variant in LRIF1 associated with facioscapulohumeral muscular dystrophy. Neurology. 2020;94:e2441-7. 